\title{
ANALISIS KESULITAN BELAJAR PESERTA DIDIK DALAM PEMBELAJARAN JARAK JAUH (PJJ) DI TENGAH PANDEMI COVID-19
}

\author{
Milana Abdillah Subarkah \\ milana.abdillah@umt.ac.id \\ (Fakultas Agama Islam, Universitas Muhammadiyah Tangerang) \\ Agus Salim \\ bani.samudra@gmail.com \\ (Fakultas Agama Islam, Universitas Muhammadiyah Tangerang)
}

\begin{abstract}
Abstrak
Proses belajar mengajar merupakan kegiatan yang sangat penting dan harus tetap dilaksanakan walaupun keadaan tidak memungkinkan di sekolah-sekolah ditengah pandemi Covid-19 seperti saat ini. Maka penelitian ini bertujuan untuk menganalisis kesulitan belajar, pembelajaran jarak jauh, dan analisis kesulitan belajar siswa di PJJ ditengah pandemi Covid-19. Penelitian ini menggunakan pendekatan kualitatif dengan jenis studi kasus, wawancara mendalam, dan studi dokumentasi. Hasil penelitian menunjukkan Pertama, kesulitan belajar pada siswa dapat dialami karena adanya gangguan pada dirinya baik dari dalam maupun luar dirinya. Kondisi ini juga bisa terjadi di tengah pandemi Covid-19. Ujung-ujungnya, melalui berbagai himbauan dari beberapa pihak, mahasiswa diminta melaksanakan kegiatan belajarnya di rumah masing-masing. Kedua, dengan himbauan dan saran mahasiswa belajar di rumah, maka Pembelajaran Jarak Jauh (PJJ) menjadi salah satu alternatif kegiatan pembelajaran bagi mahasiswa dalam rangka memutus rantai penularan virus corona. Ketiga, pada saat pandemi Covid-19 dengan PJJ siswa menghadapi kendala dalam mengakses perangkat dan kuota internet, oleh karena itu pemerintah dan seluruh penyelenggara pendidikan memberikan subsidi kuota internet, kurikulum darurat, dan mengembangkan strategi pembelajaran yang efektif bagi masyarakat terdampak Covid-19.
\end{abstract}

\section{Kata Kunci: Kesulitan Belajar, Pembelajaran Jarak Jauh (PJJ), dan Covid-19}

\begin{abstract}
The teaching and learning process is a very important activity and must be carried out even though the situation is not possible in schools amid the Covid-19 pandemic as it is today. So this study aims to analyze learning difficulties, distance learning, and analysis of student learning difficulties in PJJ amid the Covid-19 pandemic. This research uses a qualitative approach to the type of case studies, in-depth interviews, and documentation studies. The results of the study show First, learning difficulties in students can be experienced due to disruption in him both from within and outside himself. This condition can also occur amid the Covid-19 pandemic. In the end, through various appeals from several parties, students were asked to carry out their learning activities in their respective homes. Second, with the appeals and suggestions of students studying at home, then Distance Learning (PJJ) becomes an alternative learning activity for students in order to break the corona virus transmission chain. Third, during the Covid-19 pandemic with PJJ students faced problems accessing internet devices and quotas, thus the government and all education administrators to provide
\end{abstract}


internet quota subsidies, emergency curricula, and develop effective learning strategies for communities affected by Covid-19.

\section{Keywords: Learning Difficulties, Distance Learning (PJJ), and Covid-19}

\section{A. Pendahuluan}

Pada akhir tahun 2019 di Negara China tepatnya di Wuhan, beredar berita bahwa telah mewabah penyakit yang mematikan yang menyerang masyarakat Wuhan yang disebut dengan virus corona atau Covid-19. Di Indonesia kasus ini pertama kali ditemukan pada dua warga Depok, Jawa Barat awal Maret lalu. Data hingga Sabtu, 28 Maret 2020 jumlah warga yang dinyatakan positif terkena virus corona mencapai 1.155 dan 102 di antaranya meninggal dunia. Cepatnya penyebaran virus ini di Indonesia menurut Juru Bicara pemerintah untuk penanganan Covid-19, Achmad Yurianto karena banyak warga yang tak mengikuti imbauan untuk tetap di rumah.

Dengan diberlakukan pembatasan sosial kepada masyarakat yakni agar masyarakat tetap di rumah menghindari tempat-tempat keramaian dan kerumunan banyak orang. Karena penyebaran virus corona ini sangat mudah menular, bahkan orang yang sehat pun dapat tertular dan menularkan virus tersebut, dengan demikian untuk memutus mata rantai penyebaran virus pemerintah dengan sigap menghimbau agar tidak melakukan aktivitas di luar rumah sebisa mungkin menyelesaikan tugas dan pekerjaannya di rumah masing-masing yang dikenal dengan istilah WFH (Work From Home). Kemudian, pembatasan sosial ini juga berdampak pada aktivitas peserta didik di sekolah. Semua siswa serentak diliburkan sebagaimana himbauan dari menteri pendidikan melalui dinas pendidikan yang ada di daerah-daerah mengumumkan libur karna wabah Covid-19 sejak Februari hingga Juni. Kendati demikian, aktivitas belajar dan mengajar tetap dilakukan dirumah masung-masing dengan menggunakan pembelajaran jarak jauh (PJJ) / E-Learning.

Pembelajaran jarak jauh menjadi salah satu alternatif untuk dilangsungkannya proses pembelajaran, para pendidik di tuntut untuk memastikan bahwa aktivitas pembelajaran tetap berjalan walaupun dalam keadaan diberlakukannya pembatasan sosial. Maka solusi yang tepat agar pembelajaran ini tetap berjalan adalah dengan memanfaatkan media daring (online). Penerapan pembelajaran jarak jauh/ Elearning ini masih berlangsung hingga Tahun ajaran baru, seluruh sekolah disetiap jenjang mulai disibukkan untuk mengkonsep pola pembelajaran yang efektif saat masa transisi PSBB. Sebagaimana yang disampaikan oleh Menteri Pendidikan dan Kebudayaan Republik Indonesia pada surat edaran nomor 4 tahun 2020 tentang pelaksanaan kebijakan pendidikan dalam masa darurat penyebaran Covid-19. Bahkan Menteri Pendidikan telah mewacanakan pembelajaran daring masuk ke dalam kurikulum pendidikan. Dengan kondisi new normal seluruh aktivitas pendidikan harus mampu menyesuaikan pembelajaran akibat dampak covid-19 ini.

Sistem pembelajaran online dilaksanakan melalui perangkat personal computer (PC) atau laptop yang terhubung dengan koneksi jaringan internet. Para pendidik dapat melangsungkan pembelajaran bersama di waktu yang sama menggunakan grup di media sosial seperti WhatsApp (WA), telegram, instagram, aplikasi Zoom ataupun media lainnya 
sebagai media pembelajaran. ${ }^{1}$ Dengan kondisi tersebut, dari beberapa pernyataan di masyarakat terdapat para siswa yang mengalami kesulitan dalam melakukan pembelajaran jarak jauh (PJJ). Diantaranya, pertama: siswa mengeluh penugasan yang diberikan begitu banyak dan harus dikerjakan dengan waktu yang singkat, disisi lain masih banyak tugas dari guru lain. Kedua: dalam satu keluarga masih ada yang hanya memiliki satu HP dan digunakan ayahnya untuk bekerja karena profesinya sebagai pengemudi ojol (ojek online). Ketiga: beberapa peserta didik tidak mempunyai akses internet atau bahkan computer serta keterbatasan dalam mengoperasikan aplikasi pembelajaran online. Keempat: kesulitan mengikuti pelajaran karena minimnya penjelasan dari guru. Kelima, permasalahan juga terjadi pada siswa yang baru masuk sekolah di tingkat sekolah dasar, karena belum mengerti pembelajaran menggunakan media online yang masih harus didampingi oleh orang tuanya.

Kesulitan pembelajaran jarak jauh (PJJ) juga dirasakan orang tua yang bertambah bebannya karena harus menjadi guru di rumah, mengajari membuat tugastugas, dan selalu memonitor anaknya, bisa dibayangkan jika anak lebih dari satu dan masih perlu pendampingan dalam mengerjakan tugas, belum lagi harus menyiapkan makanan dan pekerjaan rumah tangga lainnya. Sedangkan bagi orang tua yang bekerja dan juga sedang menjalankan pekerjaan dari rumah, kesulitan dan tantangannya akan bertambah karena selain mendampingi anak belajar, juga mempunyai tugas pekerjaan kantor yang harus diselesaikan oleh para orang tua.

\footnotetext{
${ }^{1}$ Maria Fitriah, Transformasi Media Pembelajaran pada Masa Pandemi Covid-19, di akses dari https://www.liputan6.com/ citizen6/ read/ 4248063/opini-transformasi-media pembelajaranpada-masa-pandemi-covid-19, pada 17 Juni 2020.
}

Selanjutnya, ketidaksiapan pendidik dalam menerapkan pembelajaran jarak jauh (PJJ), karena belum terbiasa menggunakannya yang pada akhirnya penyampaian materi menjadi terhambat tidak sesuai dengan kalender pendidikan. Menurut Kementerian Pendidikan dan Kebudayaan mengungkapkan terdapat beberapa keluhan dan kesulitan yang di alami oleh guru selama kegiatan belajar mengajar dilakukan di rumah saat pandemi virus Corona (Covid-19) yaitu pertama: bagaimana cara merancang sebuah program pembelajaran yang baik. Kedua: kalau rancangan yang sudah ada, maka aspek materi atau kontennya seperti apa. Ketiga: mengalami kendala keterbatasan sarana hingga tidak ada contoh praktis pembelajaran jarak jauh (PJJ). Sebagaimana uraian diatas, terdapat berbagai persoalan terkait pemberlakuan pembelajaran jarak jauh (PJJ) pada aktifitas masyarakat. Maka penulis tertarik untuk menganalisis dan meneliti kesulitan anak belajar dirumah pada saat pembelajaran jarak jauh (PJJ) dengan judul penelitian "Analisis Kesulitan Belajar Anak Dengan Pembelajaran Jarak Jauh (PJJ) di Tengah Pandemi Covid-19”.

\section{B. Metode Penelitiaan}

Dalam melakukan penelitian ini penulis menggunakan penelitian deskriptif, yaitu melakukan pengamatan dan analisis dari berbagai peristiwa yang terjadi saat pembelajaran berlangsung ditengah pandemi covid-19.

Pertama, pada masa pandemi covod19 siswa sekolah dianjurkan melaksanakan aktivitas belajarnya di rumah yakni secara online, dengan demikian akan didapati beberapa kesulitan belajar siswa. Kedua, melakukan pengamatan dan analisis terhadap beberapa konsep pembelajaran jarak jauh. Ketiga, menganalisis kesulitas belajar siswa dengan pembelajatan jarak jauh (PJJ) di tengah pandemi covid-19. 
Dari uraian di atas, langkah selanjutnya melakukan desain deskriptif survei, untuk mengamati apa yang terjadi, pengumpulan data dengan wawancara, untuk mengetahui berbagai kendala kesulitan belajar siswa dengan metode pembelajaran jarak jauh yang dihadapi serta pemecahan terkait kendala ditengah pandemi covid-19.

\section{Hasil Dan Pembahasan}

Kesulitan belajar merupakan hambatan atau gangguan belajar pada siswa yang ditandai dengan adanya permasalahan yang signifikan antara potensi siswa dengan kemampuan akademik yang semestinya dapat dicapai. Kemudian kesulitan belajar juga dapat terjadi karena gangguan di dalam sistem saraf otak (gangguan neorobiologis) yang dapat menimbulkan gangguan perkembangan seperti gangguan perkembangan bicara, membaca, menulis, pemahaman, berhitung, dan motivasi belajar. $^{2}$

Dalam pengertian lain, kesulitan belajar adalah suatu keadaan yang menyebabkan siswa tidak dapat belajar sebagaimana mestinya, yakni siswa merasa kesukaran dalam menerima dan menyerap pembelajaran sekolah, sehingga pada akhirnya kompetensi dan prestasi yang dicapai tidak sesuai dengan kriteria standar yang telah ditetapkan. ${ }^{3}$ Terdapat beberapa kasus kesulitan belajar, sebagaimana dijelaskan oleh Abin Syamsudin dalam Mulyani, diantaranya yaitu: 1) Kasus kesulitan dengan latar belakang kurangnya motivasi dan minat belajar. 2) Kasus kesulitan yang berlatar belakang sikap

${ }^{2}$ Ridwan Idris, "Mengatasi Kesulitan Belajar dengan Pendekatan Psikologi Kognitif', (Jurnal Lentera Pendidikan, Vol. 12 No. 2: Desember 2009), h. 153

${ }^{3}$ Mulyani, "Kesulitan Belajar", diakses dari https://eprints.uny.ac.id/9124/3/bab\%202\%2004513241025.pdf, pada 26 Juni 2020. negatif guru, pelajaran, dan situasi belajar. 3) Kasus kesulitan dengan latar belakang kebiasaan belajar yang salah. 4) kasus kesulitan dengan latar belakang ketidakserasian antara kondisi objektif keragaman pribadinyadengan kondisi objektif instrumental impuls dan lingkungannya. ${ }^{4}$

Kesulitan belajar yang dialami oleh siswa sebagaimana di atas berdampak pada prestasi belajar siswa yang rendah. Siswa akan mengalami masalah dalam belajarnya biasanya terjadi beberapa gejala seperti: 1) Prestasi yang rendah atau di bawah ratarata, 2) Hasil yang dicapai tidak seimbangdengan usaha yang dilakukan, 3) Tidak maksimal dalam penyelesaian tugas sekolah. Kesulitan belajar juga dapat menyebabkan suatu keadaan yang sulit dan mungkin menimbulkan suatu keputusasaan sehingga terjadinya putus sekolah. Kemudian, kesulitan belajar pada siswa juga dapat terjadi di lingkungan rumah, bagi siswa yang kerap kali mendapatkan tugas dari gurunya disekolah, siswa akan merasa terbebani jika siswa tersebut belum membiasakan dirinya untuk mandiri dalam menyelesaikan tugas dari gurunya. Dalam situasi seperti ini, peran orang tua sangat dibutuhkan guna memotivasi siswa untuk dapat menyelesaikan tugasnya di sekolah. Tanpa dukungan penuh dari orang tua siswa akan mengalami kesulitan belajar. Selain motivasi yang diberikan orang tua kepada anaknya dalam menghadapi kesulitan belajar adalah fasilitas belajar yang tersedia untuk menciptakan suasana belajar yang menggairahkan. Fasilitas belajar mulai dari mendaftarkan siswa mengikuti kegiatan belajar nonformal dan informal, sarana prasarana pendidikan, pendampingan, lingkungan yang kondusif, dan lain sebagainya. ${ }^{5}$

\footnotetext{
${ }^{4}$ Ibid.

${ }^{5}$ Yulinda Erna Suryani, "Kesulitan Belajar", (Jurnal Pendidikan, Vol.2 No.1 Tahun 2016), h. 21
} 
Dengan demikian, kesulitan belajar berdasarkan uraian di atas dapat dipahami adalah suatu kondisi siswa yang mengalami penurunan motivasi belajar yang ditimbulkan karena adanya gangguan dari dalam maupun luar dirinya. Hal inilah yang mengakibatkan permasalahan yang dihadapi oleh siswa dalam menempuh proses pembelajaran, yang selanjutnya dapat dipecahkan untuk mendapatkan solusinya agar penurunan motivasi belajar siswa tidak berkepanjangan dan pada akhirnya siswa pun dapat kembali menumbuhkan semangat dan gairah belajarnya dalam mengembangkan kompetensinya sebagaimana tujuan dari capaian pembelajaran dari masing-masing mata pelajaran yang disampaikan kepada siswa.

Jika kesulitan belajar dikaitkan dengan kondisi yang terjadi di Indonesia saat ini yang telah mengalami pandemi covid-19, tentu akan semakin kompleks permasalahan yang terjadi dalam proses kegiatan belajar dan mengajar. Pada kondisi seperti sekarang ini seluruh aktivitas sekolah tidak dapat dilakukan secara langsung atau tatap muka di ruang kelas antara guru dan siswa, tetapi kegiatan belajar dan mengajar dilakukan di rumah masing-masing dengan sistem pembelajaran jarak jauh (PJJ). Pembelajaran Jarak Jauh (PJJ) merupakan aktivitas pembelajaran dengan menggunakan suatu media daring yang memungkinkan terjadi interaksi antara guru dan siswa. Dalam PJJ antara guru dan siswa tidak bertatap muka secara langsung di ruang kelas, dengan kata lain melalui PJJ dimungkinkan antara guru dan siswa berbeda lokasi, bahkan bisa terpisahkan dengan jarak yang sangat jauh. ${ }^{6}$ Menurut

\footnotetext{
${ }^{6}$ Ahmad Cucus, Yuthsi Aprilinda, "Pengembangan E-Learning Berbasis Multi Media Untuk Efektivitas Pembelajaran Jarak Jauh (PJJ)", (Jurnal: Explore Vol.7 No.1 Tahun 2016), h. 3
}

Moore dalam Lia Amelia bahwa pembelajaran jarak jauh adalah sekumpulan metode pengajaran dimana aktivitas pengajaran dilaksanakan secara terpisah dari aktivitas belajar. Pemisah kedua kegiatan tersebut dapat berupa jarak fisik, misalnya karena siswa ajar bertempat tinggal jauh dari lokasi sekolah/institusi pendidikan. $^{7}$

Dalam pengertian lain pembelajaran jarak jauh/ online adalah pembelajaran yang berasaskan penggunaan internet. Sedangkan Jamaludin dalam Lia Amelia menyatakan pembelajaran online adalah satu corak memperoleh ilmu atau pendidikan dengan menggunakan sistem pendekatan penyampaian pengajaran kepada siswa yang bertujuan perubahan kekal dalam diri seseorang individu dari segi mental, pemikiran, konsep, sikap dan perlakuan melalui pengalaman yang tertentu yang diuruskan melalui suatu sistem daring (online) yang mengkonsep pembelajaran, membekalkan makanisme penghantaran pengetahuan/ maklumat, pemantauan prestasi pelajar, penilaian dan capaian kepada sumber pengajaran dan pembelajaran yang ideal. ${ }^{8}$

Dengan fasilitas yang memadai untuk melakukan PJJ, selanjutnya di butuhkan jaringan internet yang baik agar lebih maksimal dalam penyampaian materi pembelajaran, walaupun keterpisahaan fisik antara guru dan siswa. Pembelajaran jarak jauh (juga disebut juga pendidikan jarak jauh) merupakan aktivitas belajar yang diberikan kepada peserta didik atau siswa yang tidak berada dalam satu ruangan secara bersama di satu tempat secara rutin untuk menerima pelajaran secara langsung dari seorang guru. Materi pembelajaran diseapkan secara detail yang bersifat khusus dijabarkan atau

\footnotetext{
${ }^{7}$ Lia Amelia, "Pembelajaran Jarak Jauh",diakses dari, pada 12 Juli 2020.

${ }^{8}$ Ibid.
} 
ditayangkan untuk para siswa yang selanjutnya melakukan tugas-tugas yang akan dievaluasi oleh guru. Dalam kenyataannya dapat dimungkinkan guru dan siswa tersebut terpisah tidak hanya secara ruang atau letak geografis namun juga waktu. Pembelajaran jarak jauh memungkinkan para siswa mengambil kelas kapanpun dan dimanapun berdasarkan jadwal yang disepakati. ${ }^{9}$

Kegiatan ini memungkinkan mereka untuk menyesuaikan pendidikan dan pembelajarannya dengan penuh tanggung jawab, pencapaian pembelajarannya dan komitmen-komitmen lainnya, seperti keluarga dan pekerjaan. Ini juga memberi kesempatan kepada para siswa yang mungkin tidak dapat belajar karena keterbatasan waktu, jarak atau dana untuk ikut serta. Tujuan dari sistem pembelajaran jarak jauh ini antara lain menerapkan aplikasi-aplikasi pendidikan jarak jauh berbasis web pada situs-situs pendidikan jarak jauh yang dikembangkan di lingkungan di Indonesia.

Sementara itu, pembelajaran jarak jauh juga memiliki keunggulan dibandingkan dengan model pendidikan konvensional yang lumrah dilakukan, diantaranya sebagai berikut:

a. Pembelajaran jarak jauh atau e-learning memungkinkan pembelajar untuk menimba ilmu tanpa harus secara fisik menghadiri kelas.

b. Pembelajaran jarak jauh dapat mempersingkat jadwal target waktu pembelajaran.

c. E-Learning menghemat biaya yang harus dikeluarkan oleh penyelenggara pendidikan.

${ }^{9}$ Safni Febri Anzar, Mardhatillah, "Analisis Kesulitan Belajar Siswa pada Pelajaran Bahasa Indonesia di SMA 20 Meulaboh Kabupaten Aceh Barat Tahun Ajaran 2015/2016", (Jurnal: Bina Gogik, Vol.4 No. 1 Tahun 2017), h. 55 d. E-Learning mempermudah interaksi antara siswa dengan bahan atau materi, siswa dan guru, instruktur maupun sesama peserta didik.

e. Fleksibilitas dari sisi waktu dan tempat. Suasana tidak menegangkan. Dengan elearning suasana belajar tidak menegangkan seperti tatap muka langsung. Siswa lebih berani melakukan latihan online karena tidak takut malu atau dimarahi kalau melakukan kesalahan.

f. Mudah meremajakan materi. Berbeda dengan meremajakan materi pelajaran yang tersusun dalam bentuk buku cetak, materi online dapat diremajakan setiap saat.

g. Peserta didik dapat merasa senang dan tidak bosan dengan materi yang diajarkan karena menggunakan alat bantu seperti video, audio dan juga dapat menggunakan alat bantu seperti komputer bagi sekolah yang sudah mempunyai peralatan komputer. ${ }^{10}$

Selain memiliki kelebihan dalam penyelenggaraan pembelajaran, PJJ juga memiliki beberapa kelemahan, diantaranya adalah:

a. Kurangnya interaksi antara guru dan siswa atau bahkan antar sesama siswa itu sendiri. Kurangnya interaksi ini bisa memperlambat terbentuknya value dalam proses pembelajaran.

b. Kecenderungan mengabaikan aspek akademik atau aspek sosial dan sebaliknya mendorong tumbuhnya aspek bisnis/komersial.

c. Masalah ketepatan dan kecepatan pengiriman modul dari puast pengelolaan pembelajaran jarak jauh

\footnotetext{
${ }^{10}$ Sri Rahayu Chandrawati, "Pemanfaatan Elearning dalam Pembelajaran", (Jurnal: Cakrawala Kependidikan, Vol. 8 No. 2 September 2010), h. 176
} 
kepada para siswa di daerah sering tidak tepat waktu, dan arenanya dapat menghambat kegiatan pembelajaran.

d. Siswa yang tidak mempunyai motivasi belajar yang tinggi cenderung gagal.

e. Tidak maksimalnya materi pembelajaran yang disampaikan kepada siswa, cenderung tidak kondusif saat pembelajaran berlangsung.

Sebagaimana uraian di atas mengenai beberapa keunggulan dan kelemahan dari PJJ dalam proses berlangsungnya pendidikan di sekolah, terlebih dalam masa pandemi virus corona tentu saja PJJ menjadi salah satu alternatif kegiatan pembelajaran yang dapat dilakukan oleh siswa, sebagai pengganti aktivitas siswa di sekolah. Hal ini merupakan langkah preventif yang dilakukan untuk memutus mata rantai penyebaran virus corona yang masih menghantui dibeberapa daerah Indonesia.

Sementara itu, niat pemerintah membuka sekolah di zona nonhijau ditentang keras. Ikan Dokter Anak Indonesia (IDAI) berikukuh, siswa harus tetap di rumah di rumah selama masa pandemi Covid-19 karena beresiko tinggi tertular dan menularkan. Ketua Umum IDAI Aman Pulungan menyampaikan, ada sejumlah alasan mengapa siswa harus tetap belajar di rumah. Salah satunya, kematian anak Indonesia akibat Covid-19 saat ini paling tinggi jika dibandingkan dengan negara-negara di Asia-Pasifik. ${ }^{11}$ Merujuk pada data IDAI, jumlah siswa sekolah terpapar Covid-19 mencapai angka ribuan, dan yang meninggal akibat Covid-19 sekitar 60 siswa. Lebih lanjut, ketua umum IDAI rasa bosan di rumah tidak sebanding dengan kesehatan anak. Mengingat, hingga kini setiap pekan ada kasus anak terpapar virus baru tersebut. Kerena itu, para orang

\footnotetext{
${ }^{11}$ Aman Pulungan, "IDAI Tolak Relaksasi Pembukaan Sekolah", Jawa Pos Edisi Selasa, 4 Agustus 2020, h. 1
}

tua menganalisis ketika anaknya harus dirawat karena Covid-19 sebelum meminta sekolah kembali dibuka. Apalagi meregang nyawa. ${ }^{12}$

Dilain pihak, Pemerintah juga diminta tidak memberikan angin surga, mengumumkan suatu daerah sudah zona hiaju, padahal masih ada kasus baru disetiap harinya. Pemerintah melalui kementerian Pendidikan Republik Indonesia juga diharapkan membuat satuan kurikulum darurat kepada siswa, dengan demikian tidak semua materi diberikan yang akhirnya membuat siswa menjadi stres. Selanjutnya, memasuki ajaran baru tahun ajaran 2020/2021, para siswa dari berbagai jenjang hingga di perguruan tinggi masih menerapkan PJJ dalam melakukan kegiatan belajar dan mengajar. Bagi siswa yang memiliki fasilitas pendidikan yang memadai hingga perhatian para orang tua yang mementingkan pendidikan terhadap buah hatinya, mungkin tidak akan berpengaruh terhadap kesulitan belajat di rumah. Para siswa akan mendapatkan materi pembelajaran yang baik dari setiap materi yang disampaikan oleh guru melalui PJJ, mulai dari metode pembelajaran, penugasan, hingga evaluasi hasil belajarnya disetiap minggunya. Karena idealnya PJJ selama masa pandemi sekarang ini terdapat beberapa hal yang melatarbelakangi keberhasilannya.

$\begin{array}{cc}\text { Menurut } & \begin{array}{c}\text { Tulus Abadi PJJ tidak } \\ \text { maksimal }\end{array} \\ \text { dalam }\end{array}$ pelaksanaannya, karena masih terdapat beberapa siswa yang memiliki keterbatasan perangkat ataupun jaringan internet. Masyarakat atau para orang tua masih mengeluhkan soal pembelajaran berbasis online. Karena hal ini berkaitan dengan biaya yang tinggi untuk membeli kuota internet. Dengan kondisi seperti ini, pemerintah semestinya memberikan

${ }^{12}$ Ibid, h. 7 
subsidi pilsa kepada masyarakat menengah ke bawah untuk mendukung PJJ. Sebeb, pengeluaran untuk internet selama PJJ terbilang tinggi. ${ }^{13}$ Namun demikian, PJJ masih menjadi cara yang aman untuk mencegah penularan Covid-19. Para pemangku kebijakan pendidikan harus kreatif dalam pelaksanaannya dan menciptakan metode pembelajaran dari rumah yang lebih murah. Dengan begitu, PJJ masih sangat diperlukan. Adapun para orang tua sudah harus memulai menyisihkan anggaran sehari-harinya untuk keperluan membeli pulsa untuk kepentingan para siswa dalam melaksanakan aktivitas pembelajaran.

\section{Kesimpulan}

Berdasarkan pembehasan di atas terkait dengan analisis kesulitan belajar peserta didik dalam pembelajaran jarak jauh (PJJ) ditengah pandemic Covid-19. Maka kesimpulannya adalah sebagi berikut:

1. Kesulitan belajar merupakan suatu keadaan siswa yang mengalami penurunan motivasi belajar yang disebabkan adanya gangguan dari dalam maupun luar dirinya. Hal tersebut diakibatkan karena situasi yang dihadapi siswa dalam menempuh proses pembelajaran. Kemudian, diharuskan untuk mendapat solusinya agar semangat dan motivasi selama berlangsungnya proses pembelajaran dapat meningkat dan pada akhirnya siswa dapat mengembangkan kompetensinya untuk mencapai tujuan pembelajaran yang telah disampaikan kepada siswa.

2. Pembelakaran jarak jauh (PJJ), adalah pembelajaran yang sangat efektif dilakukan para siswa ditengah pandemic

${ }^{13}$ Tulus Abadi, "PJJ Masih Sangat Dibutuhkan”, Jawa Pos, Edisi Selasa, 4 Agustus 2020, h. 12
Covid-19, yakni pembelajaran berbasis penggunaan internet atau online dengan menggunakan sistem pendekantan penyampaian, pengajaran kepada siswa, memberikan wawasan, dan pengetahuan dalam membina mental, pemikiran, konsep, sikap, dan perlakuakn melalui pengalaman melalui sistem daring (dalam jaringan).

3. Pelaksanaan PJJ yang terapkan selama dalam masa pandemi Covid-19, bukan tanpa masalah. Maka kepada para pemangku kebijakan dan para penyelenggara Pendidikan demi berlangsungnya aktivitas pembelajaran siswa dengan baik, diharapkan mencari berbagai solusinya mulai dari memberikan subsidi kuota internet, mengkonsep kurikulum darurat, hingga menyusun strategi pengajaran yang efektif kepada siswa pada masa seperti sekarang ini.

\section{DAFTAR PUSTAKA}

Anzar, Safni Febri, Mardhatillah, 2017. Analisis Kesulitan Belajar Siswa pada Pelajaran Bahasa Indonesia di SMA 20 Meulaboh Kabupaten Aceh Barat Tahun Ajaran 2015/2016, Jurnal: Bina Gogik, Vol.4 No. 1.

Abadi, Tulus, 2020. PJJ Masih Sangat Dibutuhkan, Jawa Pos, Edisi Selasa, 4 Agustus.

Amelia, Lia, 2010. Pembelajaran Jarak Jauh, diakses dari https:// www.academia.edu /38489745/Pembelajaran_Jarak_Ja uh.pdf.

Cucus, Ahmad, Yuthsi Aprilinda. 2016. Pengembangan E-Learning Berbasis Multi Media Untuk Efektivitas Pembelajaran Jarak Jauh (PJJ), Jurnal: Explore Vol.7 No.1.

Chandrawati, Sri Rahayu, 2010. Pemanfaatan E-learning dalam 
Pembelajaran, Jurnal: Cakrawala Kependidikan, Vol. 8 No. 2 September 2010.

Fitriah, Maria, 2020. Transformasi Media Pembelajaran pada Masa Pandemi Covid-19, di akses dari https:// www. liputan6. com/ citizen6/ read/ 4248063/opini-transformasi-mediapembelajaran-pada-masa-pandemicovid-19.

Mulyani, 2020. Kesulitan Belajar, diakses dari https:// eprints. uny.ac.id /9124 B/bab $\% 202 \% 20-$
Idris, Ridwan, 2009. Mengatasi Kesulitan Belajar dengan Pendekatan Psikologi Kognitif, Jurnal Lentera Pendidikan, Vol. 12 No. 2: Desember.

Pulungan, Aman, 2020. IDAI Tolak Relaksasi Pembukaan Sekolah, Jawa Pos Edisi Selasa, 4 Agustus.

Suryani, Yulinda Erna, 2016. Kesulitan Belajar, Jurnal Pendidikan, Vol.2 No.1. 04513241025.pdf. 
Analisis Kesulitan Belajar Peserta Didik Dalam Pembelajaran Jarak Jauh (Pjj) Di Tengah Pandemi Covid-19

Rausyan Fikr. Vol. 17 No. 1 Maret-No.2 September 2021. ISSN. 1979-0074 e-ISSN. 9772580594187 | 30 